\title{
THE PHENOMENON OF (ISLAMIC) RELIGIOUS FUN- DAMENTALISM IN A NON-'RELIGIOUS' CAMPUS: A CASE STUDY AT HASANUDDIN UNIVERSITY MAKASSAR
}

\author{
Taufani \\ University of Eastern Indonesia, Makassar
}

\begin{abstract}
This research aims to describe and examine the phenomenon of Islamic fundamentalism on the campus of Hasanuddin University (UNHAS). Islamic fundamentalism is a phenomenon that emerged after the reform and it is commonly encountered in the campus world. The trend shows that the phenomenon of Islamic fundamentalism is growing in the campus that has no particular religious affiliation and is often driven by the propagation of the Campus Dakwah Organization (LDK). This research would like to test the thesis that whether it is relevant to the context of the Hasanuddin University that in fact is not a religiously-affiliated campus or the contrary. The method of collecting data was done through observation of the activities of the LDK activist at the Hasanuddin University (UNHAS) Campus Dakwah Organization's Musholla Lovers (LDK$M P M)$, in-depth interviews, documentation/review of previous research and papers. This research shows that Islamic fundamentalism led by LDK-MPM is growing at the Hasanuddin University. This phenomenon emerged as the implications of the post-reform freedom, so that these opportunities are exploited by activists to channel their euphoria, because at the time of the new order, their propagation had a fairly limited space. Another factor that led to the rise of Islamic fundamentalism and growing at Hasanuddin University is because the students did not have comprehensive Islamic references, so that they had no checklist for critiquing and examining the ideology of Islamic fundamentalism. In addition, the emergence of modernity considered to bring the negative excesses also serves as another factor being the cause of Islamic fundamentalism. Therefore, the ideology of Islamic fundamentalism emerged as an alternative to counteract the negative excesses.
\end{abstract}

Keywords: Islamic Fundamentalism, LDK-MPM, Hasanuddin University.

\section{INTRODUCTION}

After the devastating fall of Suharto's leadership in 1998 led by civil society, particularly the university students, there have been a lot of significant changes in Indonesia. At the time of the New Order led by Suharto, there 
was almost no freedom of speech and expression, because the ruling regime was authoritarian. Anyone who dared to criticize government policy or held demonstrations in public spaces, they will be arrested and thrown in jail because they were considered a barrier to development, anti-Pancasila, or non-pancasilaists.

However, after the advent of the era of reform which is the antithesis of the new order era, the civil society movement is flourishing, marked by the birth of various civic organizations in different areas. The movement focuses on the educational process in the community with a variety of contemporary themes --such as human rights, democracy, and pluralism-- through seminars, training, and publications. The fall of the new order regime also brings positive aura to the rising euphoria of activism on campus because at the time of the new order, movement of students was restricted through regulation of the normalization of campus life (NKK) 1978. New order regime did not hesitate a militaristic ways for fighting against student activists who had a strong tendency in practical politics and Government opposition.

After the reform, the campus is no longer allergic to discussion of political themes. A variety of student movements, driven by the visionary and idealistic youth, emerged with certain identities and ideological reasons. One of them is the growing movement using the campus Islamic religious label (read: Islam) as the main spirit of their struggle. The inherent characteristics of the movement are focused on activities in mosques, such as the recitation, Islamic book reviews, tarbiyah (Dakwah and education). In General, the physical characteristics of the male Muslim activists (ikhwa) are as follows: growing beard, wearing pants above the ankles (cingkrang), koko shirt, and usually having a black mark on the forehead. Whereas, female activists (akhwat), usually have a longer scarf that almost covers the whole body like Afghan and Saudi women. They also typically use a variety of the Arabic language terms in communication, such as antum (you).

These movements tend to take the form of activities through social and cultural activism that is far from the formal political arena (Hilmy, 2010: 101). Within the community, they often play an important role in the spread of ideology. In spreading its ideology, they are usually supported by the established Islamic organizations such as Hizbut-Tahrir, Wahdah Islamiyah, etc. The pattern of religious thought that they promote is the pattern of Islamic fundamentalism that tends to see things in black and white.

Nowadays, there is a tendency to suggest that Islamic fundamentalism today is flourishing on campuses that have no specific religious affiliation and are usually driven by propagation of the Campus Dakwah Organization (LDK), 
as described by Erham Budi Wiranto (2010) in his study that examined the Natural and Social Science students at the University of Gadjah Mada (UGM). In addition, various studies that have been carried out by scholars show that the advent of Islamic fundamentalism in the campus, started with LDK based on campuses that have no religious affiliation, i.e. at the Bandung Institute of Technology (ITB) and then developed in other large campuses. Instead, the pattern of religious thought which is liberal and contrary to Islamic fundamentalism, even thrives in religiously-affiliated campuses, as was the case at the State Islamic University (UIN) of Sunan Kalijaga and Syarif Hidayatullah. The view then created the image that the campus was the second funnel, the birth of liberal Islam, where UIN Syarif Hidayatullah known as Ciputat School of thought and UIN Sunan Kalijaga as Sapen School of thought (Zuly Qadir, 2007).

In this study, I would like to test the thesis that shows a trend of Islamic fundamentalism at a campus that has no religious affiliation. In this case, I chose the Hasanuddin University (UNHAS) as the location of the research because it is one of the largest in Makassar and Eastern Indonesia, which is not affiliated with a particular religion. In this campus, there is a student religious organization called the Campus Dakwah Organization's Mushalla Lovers (LDK-MPM), which has a fairly strong and significant influence on the students of UNHAS. This study attempts to examine whether the LDKMPM has the tendency of fundamentalist religious thought as commonly found in other campuses with no affiliation to religion. If so, then what are the characteristics of the fundamentalism? And what factors have strong influence on it?

\section{FRAMEWORK}

Fundamentalism is a term first coined by the Protestants in the 20th century, which was marked by a religious resistance against the products of modernity that are considered to have destroyed the sanctity of religion. This view assumes that religious teachings gathered in the Bible are something that is final, so it must be executed with full obedience because the Bible does not contain errors at all (James Barr, 1996: 1). Further, Barr said that Christian fundamentalism, also put a deep hatred in modern theology because the framework uses the epistemological method of the study of modern criticism against the Bible.

Karen Amrstrong (2011) argued that one of the traits of Christian fundamentalism is that its supporters have always had a sense of danger on a variety of new things because of fear of attacking the sanctity of their 
religion, therefore they tend to be very defensive and closed to any new idea. To counter any belief considered wrong, they willingly take various strategies such as campaigning to ban the teaching of evolution in schools and condemning democracy, feminism, and the practice of abortion since the latter is considered to be the product of modernity. They even do not hesitate to use violence to enforce the doctrine and views, i.e. by killing the doctors and nurses who work in abortion clinics.

Their actions are motivated by the belief that the doctrine of the Bible is final and each paragraph on the Scripture should be interpreted literally. The other characteristics of Christian fundamentalism are opposing diversity and labeling others are different from them negative, for example Muslims and the Jews are regarded as dwellers of hell and some of them consider that the followers of Hinduism, Buddhism, and Taoism are followers of Satan (Armstrong, 2011: 470).

Further, Armstrong, said that in defending their beliefs and views, Christians fundamentalists are selective in reading the Scriptures, so Armstrong (2011: 470) explicitly said that, "in all its forms, fundamentalism is a very reductive faith." They only quote the teachings that can justify their actions, but ignore ideas that brought on the kindness and peace, such as Jesus' sermon on the hill that tells his followers to love their enemies, give the other cheek, and not judge others.

The phenomenon of religious fundamentalism is not only found among the Protestants, it also occurs in the Islamic world. Islamic fundamentalists sometimes ignore the teachings of the Koran which encourage every Muslim to spread love, tolerance and peace. Instead they only cite verses that can justify their violence. When traced back, the Islamic fundamentalism first appeared in the 1960s, after the Arab community lost the six-day war against Israel. The failure of the ideology of nationalism and socialism in the West got a place in the hearts of the Arab community, and also encouraged the birth of religious zeal into identity and also inspired the birth of a struggle that led to the movement of Islamic fundamentalism

The policies of Western countries which are considered to intervene the sovereignty of countries in the Middle East have also triggered the rise of Islamic fundamentalism. The United States and the United Kingdom had conspired to overthrow the existing governments, and then changed them to a puppet government in order for the US and UK to smoothly secure their interests in the Middle East. The overthrow of Muhammad Mosadeq by Shah Muhammad Reza Pahlavi who was backed by the CIA and the British intelligence is a real example of American and British intervention. The 
intervention has destroyed morale, self esteem and pride of the people of the Middle East on their land, because they are helpless against such intrusion.

The failure of the international community to help the Palestinians make the most of them disappointed and lose confidence in the conventional political process. The double standard practiced by the West with the boast of democracy and freedom, but on the other hand supports the Government of dictators, like Saddam Hussein and Shah gave rise to radicalization of Islam, so the ideology of Islamic fundamentalism is growing increasingly strong. Islamic fundamentalism also emerged because the Government of Gamal Abdul Nasser who led Egypt at that time held thousands of Muslim Brotherhood activists led by Sayyid Qutb and imprisoned them without going through court proceedings. In prison, these activists received extremely bad treatment but it did not change their determination. Instead, they were growing increasingly radical and stood against what they deemed as ignorance such as Nasser, the West, Jews, Christians, capitalists, and Communists.

In recent years, we have been familiar with a wide range of violent acts committed by supporters of the ideology of Islamic fundamentalism. They bombed and destroyed numerous public facilities, such as embassies, tourist spots, and places of worship on the pretext of jihad to uphold Islam. They also condemned the modernity because it is considered as a product of the West that only brings negative excesses on Muslims. Islamic fundamentalism is in fact one of the global phenomena emerging in recent years, in which it often uses the label of religion in its action, but the issues it brings stresses more on political ideology. They argue that a world order shaped by the West, have failed to organize the world, so it needs to be replaced with a new order, the order of Islam that is based on their political interpretation.

According to Ahmad Jainuri (2003), the emergence of Islamic fundamentalism aims to revive Islam in the past, in response and reaction to the decline of the Muslims in various fields of life, as well as the antithesis of the West's failure to answer the problems of Muslims. Indeed, when talking about fundamentalism, many scholars recognize that the term is very problematic, since this term literally refers to the importance of every follower of religion to be subservient and obedient on basic principles and tenets of the religion. However, nowadays, the meaning of fundamentalism has narrowed the meaning which is defined as the restriction of the Holy Book against various new interpretations.

In order not to get caught up in the complexities of fundamentalism, the designation of fundamentalism is necessary because the pattern of fundamentalism has a lot of varieties. There is a fundamentalist movement that does not hesitate to use an aggressive and radical approach towards those 
whom they considered different. I refer to it as extremist fundamentalism. However, there is also a fundamentalist movement that uses a pragmatic approach and tries to avoid street violence in responding to the difference. I refer to it as gradualist fundamentalism. Both are different in terms of models and methods of struggle, but they complement each other in epistemic communities that have the same goals and agenda, i.e. the purification of religion from various non-Islamic ideas, interpretation of the text of Scripture textually, and implementation of Islamic Law at the State level.

In the context of LDK-MPM, their pattern of religious thought can be categorized as the gradualist fundamentalism because they prefer to use a pragmatic approach that prefers the process of a tiered education through its cadres. In their action, they avoid harsh approach against the system, but instead chose a more pragmatic approach to take advantage of a variety of devices to achieve political goals.

\section{THE HISTORY OF THE EMERGENCE OF LDK}

In 1945, there was a heated debate between nationalists represented by Sukarno-Hatta and the stronghold of the Islamists represented by Natsir with the Masyumi party who attempted to enact the Jakarta Charter into a formal legal system in Indonesia. The debate took place quite a long time and reached its peak when Masyumi was dissolved by President Sukarno in 1960 (Anwar, 2006: 765). During the New Order era, the Masyumi tried to resurface and take a role. However, the fate of Masyumi was unchanged because it was still considered a threat second only to the Communists as Natsir said that "the New Order regime treated us like an 'ugly cat' (badly)" (McVey in Anwar, 2006: 767).

Over time, Natsir never got frustrated and discouraged against the forces of the regime the Government that has destroyed the power of his party. $\mathrm{He}$ then changed his movement's strategy, namely by taking part in the Dakwah field. He then founded the Board of Dakwah Islamiyah Indonesia (DDII), and was also one of the founders in the establishment of Institution of Islamic and Arabic Sciences (LIPIA) which was a branch of the Islamic University of Muhammad Ibn Sa'ud in Riyadh. LIPIA received a lot of fresh financial assistance from Saudi Arabia. LIPIA gave a lot of important contribution in introducing the ideas of the Muslim Brotherhood in Indonesia through its teachers which have a strong background of the translation of the books of intellectual works of the Muslim Brotherhood. In addition to promoting the ideas of the Muslim Brotherhood, the curriculum in LIPIA also widely 
promoted the idea that Ibn Taimiyah is the main reference figure in Islamic doctrine in Saudi Arabia (Fealy and Bubalo, 2005).

Natsir had a very close relationship with Saudi Arabia because he was a member of the World Moslem League sponsored by Saudi Arabia (Van Bruinessen, 2008, 2009; Burhanuddin, 2007). From the membership, Natsir later facilitated the Indonesian students to study in the Middle East with the help of a scholarship from Saudi Arabia, before the role was taken over by the Ministry of Religious Affairs (Rahmat, 2008: 91). Indisputably, Natsir was the major pioneer of the Islamic movement in campuses, which was later developed by actors who had taken part in the activity of DDII and LIPIA. It is well known that the DDII has three main targets in its dakwah, i.e. the boarding school, the mosque, and the campus (Rahmat, 2008: 26). DDII supported the activities of several boarding schools such as Gontor, Al-Albab and Ngruki. However, DDII was disappointed by the DDII Gontor because the latter produced liberal Muslim thinkers like Nurcholish Madjid, but on the other hand DDII successfully introduced salafi thought at Ulil Albab in Bogor and the Ngruki in Solo that makes them different from other religious schools that generally have traditional style (Van Bruinsessen, 2008).

The DDII also served as the manager of fund provided by the Middle East in the construction of mosques in Indonesia. Therefore, the DDII was given full responsibility for the development of various activities of Dakwah in the mosques. In addition to religious schools and mosques, the DDII also expanded its influence in campuses by recruiting cadres for Dakwah activities called Training of Dakwah Mujahid (LMD). This event originally started at Salman Mosque of ITB Bandung in 1974 and later gave birth to the movement of Tarbiyah, Hizbut Tahrir and Salafi Movement (Rahmat, 2008).

Because of the strong government repression against political activity on campus in the mid-1970s until the late 1980s, then campus Dakwah activists chose to perform their dakwah covertly, often called usroh. This activity was divided into several groups consisting of 6-10 people and led by a supervisor (murabbi). Their activities were often camouflaged as regular student activities, such as study groups that discuss thought-provoking Islamic figures such as, Hasan Al-Banna, Sayyid Qutb, Ali Syariati, and Murtadha Mutahhari. It had to be done because they worried about the repression of the regime of the New Order that scrutinized religious movements and various political activities on campus as a result of the promulgation of the rules of normalization of campus life (NKK) 1978 (Damanik, 2002: 354; Hwang, 2011: 82). However what makes these activists more excited and confident in continuing their activism in Dakwah and cultivating political Islam amid threats of repression 
is the momentum the success of Iran's revolution in 1979 which brings the spirit of Islam.

As stated previously, campus Dawah activities called LMD was first held at the Salman Mosque of ITB Bandung. The Dakwah activities were instructed by Imanuddin Abdurrahim. Before becoming an instructor at LMD, he was trained by DDII in his capacity as one of the instructors through community development activities at the Hajj Dormitory in Kwitang, Jakarta. Imanuddin was one of the pioneers who gave many contributions in introducing the movement of the Muslim Brotherhood to the activists of the campus Dakwah. Thoughts about the movement were gained while he was active in the international Islamic movement (Rahmat, 2005: 85).

LMD event at the Salman Mosques of ITB at that time was attended by not only students in the vicinity of the city of Bandung, but also students coming from other cities such as students of the Indonesia University Jakarta, IPB Bogor, and Gadjah Mada University Yogyakarta. Students who took part in the whole series of activities of the LMD then became preachers, both in their own campuses and in others. After that, they developed the usroh that once they got at the Salman mosque of.

To develop Islamic propagation in the campus, the DDII was the precursor to the LMD, doing various activities of the strategic approach with a variety of campus constituents in order to push the construction of mosques so as to serve as a place to conduct Dakwah activities. Over time, several mosques were constructed, both in and around the area of the campus. The mosques later became the base for the struggle and the spread of Islamic discourse by the campus Dakwah activists through various activities such as religious instruction, discussion about the thought of Islam, and book reviews. These religious activities then became the forerunner of the inception of propagation of the LDK.

The LDK is increasingly growing because the cadres who were trained at the Salman mosque have penetrated into almost all corners of the campus in Indonesia and in General, they are very active in Dakwah activities. Studies conducted by Rahmat (2008) revealed that almost the entire campus Dakwah activities at several public universities in Yogyakarta, such as Gadjah Mada University (UGM), Yogyakarta State University (UNY), Indonesia Islamic University (UII), and University of Pembangunan Nasional Veteran (Veteran UPN) were conducted by the alumni of the Salman Mosque came from the UGM campus. Campus Dakwah activities also grew in Jakarta at the Indonesia University, where the centers for research and Islamic studies integrated in some faculty were increasingly growing. Meanwhile, in Bogor the campus 
Dawah activities successfully controlled the campus mosque at the Bogor Institute of Agriculture (IPB), namely Al Ghifari mosque which later became the birthplace of the movement of the Hizbut Tahrir Indonesia (HTI).

The LDK's at the ITB, UGM, UI, and IPB were successful early generations shaped by campus Dakwah activities which later on successfully expanded their institution by training and educating activists from other campuses. Their efforts paid off because they apparently managed to create a lot of new cadres that later spread to reach large public universities, such as UNAIR Surabaya, UNDIP Semarang, UNHAS Makassar and USU Medan (Rahmat, 2008: 29). Since then, the campus Dakwah activities have increasingly grown and developed from Aceh to Papua and penetrated public and private universities and several religiously-based universities (Rahmat, 2008:29)

To corroborate the existence of the LDK in the campus, the LDK activists used a variety of strategies and approaches. One of them was by taking part in important positions in the intra-campus institutional structure so that their activities could get support and legitimacy. The LDK had also become more powerful because it was supported by the alumni in the Middle East who routinely provided important contribution in the development of Islamic teaching materials. The Islamic teaching materials developed were ideas that they got while pursuing an education in the Middle East, one of which was the idea brought in by the Muslim Brotherhood movement, which was the Islamic discourse that was popular in the late 1980s (Rahmat, 2008: 88). The alumni of the Middle East also spent a lot of their time serving as a supervisor and murabbi for lectures, studies, and seminars related to religious issues that are regularly held by the LDK.

Nowadays, the LDK has a national network of dakwah followed by various campus dakwah institutions in several universities in Indonesia. The Campus Dakwah Organization Hospitality Forum (FS-LDK) and the Indonesian Student Dakwah Circle (LIDMI) are national network of dakwah owned by LDK. The network always holds regular annual meetings in various cities and in their meetings they usually discuss contemporary issues, consolidation of power, and the future of Islamic propagation.

\section{HISTORY OF ESTABLISHMENT OF THE LDK-MPM}

According to its official site, LDK-MPM was founded on December 15, 1988. LDK-MPM is a unit of student activities of the campus Dakwah institutions focusing on social, dakwah, and educational activities. LDK MPM UNHAS was founded to answer the challenges of the globalization era in order to 
realize a shared vision to embody the Hasanuddin University (UNHAS) into a College with Islamic atmosphere. AN (22), one of the activists of the LDKMPM said that at first the LDK-MPM was present on the old campus of the Hasanuddin University in the area of Baraya, before moving to a new campus located in the area of Tamalanrea.

The birth of this organization began when several students that wanted to say prayer often had difficulty finding small mosque for the ritual. They then use the attic at the campus for a place of prayer. At first, they said prayer there quietly, but over time, they eventually were given permission to turn the attic into a small mosque. From the small mosque, they then held a variety of activities such as Islamic religious instruction, discussion, and prayer in congregation, but not openly.

When the old campus of Hasanuddin University was moved to the new one which is located in the Tamalanrea, the students who had enthusiasm in the activities of dakwah, took the initiative to find a place that was unused in the campus area to be used as a small mosque. In short, starting from the small mosque in the new campus, gradually, LDK-MPM tried to stretch their influence by recruiting and training students who have a great interest in the activities of Islamic propagation. This was aided by several activists who had also previously been in the field of dakwah. At that time, the new order Government issued a policy that prohibits students to get involved in practical politics, so the campus activities were deserted. The LDK-MPM became an oasis amid the vacuum of student activities at that time. Campus Dakwah activities emerged as an alternative for students. Since the campus Dakwah activities were solely considered purely religious in nature to help students improve themselves and that religiosity was thought as having no political pretensions to oppose the Government, the campus Dakwah movement received considerable support in the campus (Muhtadi, 2012: 103-104).

One of the LDK-MPM activist said that due to the increasing number of students of the Hasanuddin University who came from different parts of Eastern Indonesia, the university steak-holders realized the importance of the presence of a bigger mosque because small mosques that had been there before were no longer able to accommodate worshipers who were increasingly growing day by day. Several lecturers then initiated to set aside a portion of their income to help with the cost of construction of the Campus Mosque. Students also contributed by setting aside some of their money to speed up the construction of the mosque. Finally, the construction could be done quickly after the Committee for the construction of the campus mosque at that time received a sizable donation from South Sulawesi Governor, H.Z.B Palaguna 
and also from BJ Habibie, who at that time served as the General Chairman of the Indonesian Muslim Intellectuals (ICMI) and the Minister of Research and Technology. Finally, on September 13, 1997, B.J.Habibie as the Chairman of ICMI officially opened the mosques as the campus activity center of worship and preaching.

The campus mosque today serves as one of the main bases for the LDK-MPM activists' Dakwah activities. In addition to the campus mosque, LDK-MPM activists also had a lot of dakwah activities in smaller mosques run by the LDF (branch at the faculty level), which is a wing of their movement. Dakwah activities were chosen because these activities are regarded as a strategic way to spread the ideology of Islamic fundamentalism. In their activities, one-way communication patterns tend to be very prominent, so the process of ideology instillation can run easily. Zuly Qadir (2007) showed that the activities of religious propagation conducted by the campus dakwah body were a mere camouflage. At first, they only appeared as a dakwah movement, but today they have shown their ideological face.

\section{TRAITS AND CHARACTERISTICS OF ISLAMIC FUNDAMENTALISM CARRIED BY LDK-MPM}

Hasanuddin University a public campus that is basically does not have a specific religious affiliation, so ideally this should be home to students of various religions, ethnic groups, race, gender or ideology. However, it would be gone instantly because lately, the ideology of Islamic fundamentalism led by LDK-MPM was growing strongly at Hasanuddin University. Adherents of these ideologies have always wanted uniformity, something they believe to be the absolute truth. It can be seen from several indicators as follows:

\section{Rejecting Modern Views}

In view of the LDK-MPM activists, the modern world is always seen as something synonymous with the West. They argue that the West is a wily enemy, so they must remain wary, because the West is considered to have a specific agenda to destroy the faith of Muslims. According to them, most Muslims today have left the values of Islam and prefer to exalt the Western values in everyday life, such as the freedom of sex and alcohol consumption. The negative excesses arising out of the penetration of Western civilization have made the Dakwah activists feel the need to fortify the Muslims so that they will not go astray. With the spread of the ideology of Islamic fundamentalism, they believe it will provide solutions to the decline of Muslim morality.

According to the I.M., one of the West's views that contradicts the teachings 
of Islam and had to be abandoned by the Muslims is democracy. I.M. further revealed that:

"Democracy is not a product of Islam, since the legal basis taken in it is based on the secular law that does not have a strong foundation in the Qur'an and Hadith.”

However, the LDK-MPM activists realize that it takes a long process to implement the application of Sharia Islamic law in the country. To make it happen, then they shall not give up in searching for and educate new cadres. They assume that the cadre recruitment is a necessity, because it is the right and realistic way to prepare the best cadres in the fight for the aspirations of Muslims, namely the total and complete application of Islamic law at the state level. For them, to reach their goal, the campus is the initial starting point, because it is a conducive place in which each ideology can develop.

To manage that, then the LDK-MPM activists employ a variety of strategies, one of which is to consolidate all of their resources to strengthen the work of the LDF, in order to achieve the vision to embody the Hasanuddin University as a campus with Islamic atmosphere. The definition Islamic atmosphere in their views is when any student can literally talk about Islam, occupy themselves for Islamic rituals and dress according to Islamic values, especially for women. In addition, the Islamization of public space is also occurs another strategy for LDK-MPM activists to promote Islamic values at the micro level before stepping into the application of Islamic Sharia at the state macro-level.

One example of Islamization of public space is applying certain norms in areas that become their main base, such as the on-campus Mosque, the park and the lake. When we set foot in those areas, we will see a wide banner that reads "courtship is prohibited" which features a quote from one of the verse in the Quran, i.e. Surah Al-Isra verse 32 which reads "And do not approach unlawful sexual intercourse. Indeed, it is ever an immorality and is evil as a way." In carrying out the norms in the area, the LDK-MPM activists do not hesitate to remind and give spiritual sermon on couples who are discovered being alone. This step is a way to counter the negative excesses of modernity, which is thought to have destroyed the morality of Muslims. In addition, the Islamization of public space is intended to strengthen the image of LDK-MPM as guardians of moral values.

\section{Anti Diversity}

The term pluralism nowadays is one of the many terms that sparks controversy 
in the Islamic world, especially in Indonesia, due to the fatwa of the Indonesian Ulema Council (MUI) in 2005 that banned Secularism, Pluralism and Liberalism or often referred to as SEPILIS. Regarding pluralism, in the views of the LDK-MPM activists, this is considered a heretical doctrine it considers all religions are the same. For LDK-MPM activists, the true religion of Allah is Islam, so it is feared it would undermine and destroy the established Islamic teachings.

To prevent the development of pluralism among students, the LDK-MPM always counter the opinion of the Liberal Islam Network (JIL), which is deemed as a motor of the growing movement of pluralism through a variety of activities such as socializing in social media, education, publications, and seminars. The LDK-MPM activists assume that JIL is group to watch out because its followers were minions of the West and the Jews who purposely want to destroy Islam through the war of thought (al ghaz wal-fikri). For them, the JIL have destroyed the established Islamic foundation. JN (23), one of the activists of the LDK-MPM stated disagreement on the presence of JIL, because it is considered as one of the masterminds behind the inception of Bill Justice and Gender Equality (RUU KKG). To LDK-MPM, the bill is problematic and does not need to be defended, gender equality is the Western idea. They are very resistant to the concept of gender equality, as it provides a large space to the existence of gays and lesbians in the future. JN further said:

"Supporting the Bill justifies the existence of gays and lesbians, because Islamic teachings strongly condemn their existence because they have belied the nature given by Allah."

In addition to countering the JILL, the LDK-MPM activists are also actively involved in the movement of religious purification of the sects regarded as 'perverse', i.e. the Ahmadiya and Shia. In their views, the Ahmadiya is heretical, so they must fortify the Muslims from the sect. However, preaching against the Ahmadiya is not as big an issue that discusses the Shia heretics. IM asserted that,

"My friends and I do not worry too much about the Ahmadiya because a sane Muslim will surely not ask critically about the teaching that recognizes a prophet after Prophet Mohammed, who in fact has clearly been said in the Quran as the last Prophet and Apostle."

In the view of LDK-MPM activists, the Shia needs to look out for because the teachings are thought to have damaged Islam and tend to be double- 
faced. They have the perception that the followers of Shia often promote their teachings as part of Islam, but in fact they are deemed to have deviated far from the doctrine of Ahlusunnah Wal Jamaah which they believe. JN, one of the activists of the LDK-MPM, assumed that the ta'qiyah which becomes the cornerstone of creed for the followers of Shia, is considered problematic and a misleading doctrine, because it gives opportunities to the followers of Shia to justify lies in order to smooth the spread of Shiite teachings.

The LDK-MPM activists consider the Shia as apostates as their teachings have deviated from Islam, and its followers are considered to have wounded the sanctity of the Prophet Muhammad's wife, Aisya, whom they accused of adultery. For LDK-MPM activists, Aisya is one of good examples in Islam, because historically she narrated the Hadith of the Prophet, so she must be defended. In addition, the Shia are considered to laud Ali Ibn Abi Talib too much and humiliated the companions of the Prophet, such as Abu Bakr, Umar Ibn Al-Khattab and Uthman Ibn Affan. The Shia also legalize contract marriage that LDK-MPM activists believe to have been removed by the Prophet, so it should be abandoned by Muslims.

To combat the teachings that are considered astray, the LDK-MPM activists strive to utilize the medium of propagation to purify Islam from various things regarded as Un-Islamic. They utilize the media as effectively as possible because the communication pattern in their Dakwah tends to run in one direction, so that the ideology instilment can run easily. It is not difficult for LDK-MPM to spread their ideology, because basically, almost all mosques and small mosques located in different faculties at the Hasanuddin University have been dominated and controlled by them and the LDF which becomes a wing of their movement. The LDK-MPM activists can designate a trainer/ presenter whose agendas and objectives are the same as their ideology for a talk at religious gatherings. Therefore, in its action, the LDK-MPM often involves speakers from WI (United Islam), LPPI (Institute for Islamic Studies and Research) and MIUMI (Assembly of Young Intellectuals and Scholars of Indonesia) because these organizations are concerned with the issue of the war thought (al ghaz wal-fikri).

In addition, LDK-MPM uses (Intensive Study of the Qur'an) media to transmit their ideology and socilize to Muslims with regard to the sects labeled as heretical. SAINS Media is one of the most effective media for those running the mission because this activity was followed by a lot of new students whose mind is still plain, so that they become objects of prospective cadre recruitment. The LDK-MPM activists appeared as a mentor in charge of providing guidance regarding the procedures for the correct reading and 
also thematic discussions in which the ideology of Islamic fundamentalism is often instilled and taught in the discussions.

\section{Rejecting New Interpretation The Text}

The text is something that is dynamic and flexible since no text is dropped in space without meaning, so text reinterpretation is inevitable. Islam is the teaching that rests a lot on the text, especially the Quran and Hadith. In the view of the LDK-MPM activists with fundamentalist tendencies, the interpretation of the text in the Qur'an is final, sacred, and can no longer be contested. For them, Islam is a complete teaching and being a complement to the teachings of the previous religions. To preserve the sanctity of Holy Scripture, they strive to purification efforts. Purification in question is anything practiced by Prophet Muhammad should be maintained and preserved by the Muslims as the Prophet is model for Muslims.

To carry out the purification, they implement everything that is considered Islamic prophetic tradition, such as growing a beard and wearing pants above the knee (cingkrang). These LDK-MPM activists reject everything of foreign nature to Islam, particularly the influence of the West. One of the things that they reject is interpretation of the text by using the hermeneutics method which is nowadays widely used by the Muslims who have a pattern of liberal thought. For them, Islam is a doctrine that has been perfect and suited to a wide range of ages, so no longer need to be interpreted with the method of hermeneutics. They criticize the hermeneutics method because it is often used by Westerners to criticize the Gospels. For them, in terms of content, the Bible and the Quran are very different. The authenticity of the Bible is questionable because the content has been revised by humans, whereas the Quran has always maintained its authenticity. For them, the use of the method of hermeneutics for the Qur'an will only harass the grandeur and authenticity of the Holy Book.

\section{FACTORS THAT LED TO THE RISE AND GROWTH OF ISLAMIC FUNDAMENTALISM AT HASANUDDIN UNIVERSITY}

The campus is a place that is conducive and convenient in which various ideologies can grow fast. The intellectual climate of the campus that provides maximum space of freedom of thinking and academic freedom becomes a major factor why an ideology can be developed easily. High curiosity towards new thing among students makes the campus a strategic place to the spread of an ideology. The campus Hasanuddin University is one of the campuses in 
Makassar where various ideologies are growing. Each ideology is contesting each other for the realization of their main agenda, namely making their reference values as dominant (Taufani, 2012).

One of the prominent and dominant ideologies propagated at UNHAS is the Islamic fundamentalism transmitted and reproduced by LDK-MPM. This ideology strives to implement Islamic values as they argue that Islam is taught by the former salaf, i.e. Prophet Muhammad, his companions, and scholars of the past. For them, Islam is the doctrine that is final, complete and capable of managing various aspects of life, so whatever we want to do, everything has been arranged in the Quran and Hadith. "We do not need to follow the interpretation of Islam by those who like to interpret the Qur'an according to their own sense and their lust," said one of the activists, IM (23). For him, the modern interpretation of Islam is a perversion of Islam.

The thought pattern of Islamic fundamentalism grew rapidly at Hasanuddin University due to the climate of freedom after the reform. As we know it, the New Order Regime under Suharto outlawed all activities of practical politics in the campus through the law of normalization of campus life (NKK) 1978 (Damanik, 2002: 354; Hwang, 2011: 82). The New Order Regime also gave no space on any movement to spread any ideology other than Pancasila which was regarded as final. Therefore, the LDK-MPM activists try to avoid the ideological nature of the propagation and select activities Dakwah that its study and discussion, so that they get acceptance on campus, since their activities are considered to be solely aimed at improving students' religiosity.

Other factors that cause the pattern of fundamentalist thought to thrive at Hasanuddin University are a lack of references to Islam and poor Arabic language skills of the students, so that various discourses offered by LDK-MPM activists have been difficult to stop, because students have no comparison in critiquing and reviewing the notion of Islamic fundamentalism. The limited portion of the Islamic religious education course (PAI) which is only 2 credits in the entire period of the studies has further caused the students to fail to enrich their reference regarding diversity in Islam, because the PAI course stresses more about aspects of ritual and fiqh, while the subjects of Islamic philosophy, kalam, Sufism, and History of Islamic culture are rarely touched.

Most students who join the activism of fundamentalist Islam are those from the Faculty of natural sciences, especially the students of the mathematics and natural sciences department. There are also students of the faculty of social sciences joining this movement, but are outnumbered by the quantity of students of the Faculty of natural sciences. The cause of this trend is due to the fact that the activists from the natural sciences department often play 
an important role in the management of the Faculty Senate, so that they can master the political tools in it to launch a process of ideology instilment. Unlike in the Faculty of social sciences, particularly in social and Political Sciences, the dakwah body tends to be stagnant and the system of cadre recruitment does not run well.

In addition, the emergence of the ideology of Islamic fundamentalism in the Faculty of natural sciences, particularly the department of mathematics and natural sciences, is caused by the viewpoints of students who are accustomed to something that is mathematically measurable and rational, so that it is correlated to the viewpoints that they interpret holy texts to be black and white, without critical examination. On the contrary, the ideology of Islamic fundamentalism is not popular among the students of social sciences because basically they have a tradition of critical thinking that is a tradition in the study of the social sciences, so they are always skeptical of new ideas. Social science students also come into contact with a lot of cross cultural studies and multiculturalism, so they always analyze things from a variety of perspectives (Erham Budi Wiranto, 2013: 111).

Another factor that led to the growth of Islamic fundamentalism at the Hasanuddin University is modernity that is always associated as Western culture and considered to be negative, so the ideology of Islamic fundamentalism, in this respect, appears to be an alternative to counteract the excesses of the negative influence of the West. The LDK-MPM activists assume that there is a shift in the values that occur to Muslims, especially among the younger generation of today. They assume that most of the younger generation of Muslims nowadays cannot adapt to modernity. They tend to get carried away, so they ignore moral values. IM gave examples of what is going on in the campus where a female college student is not dressed in accordance with Islamic norms and the lack of confidence when they do not have a boyfriend. IM argued:

"Dating is prohibited because of the negative effects, for example when two people of different sex are being alone, the devil will be in the middle of them and persuade them to do bad things."

The above discussion shows that the presence of LDK-MPM that brings the ideology of Islamic fundamentalism inside the campus aims to identify themselves as the antithesis of the moral corruption brought on by modernity. 


\section{CONCLUSION}

Islamic fundamentalism has become quite familiar and is commonly encountered today. The phenomenon essentially resulted from the excesses of the post-reform freedom. The pattern of thought that is typical of Islamic fundamentalism is a narrow and textual understanding of Islamic teachings. They believe that whatever has been formulated in the text of the Holy Qur'an, must be interpreted literally. The Hasanuddin University campus is not affiliated to a particular religion, but religious tendencies are growing strongly here in the form of Islamic fundamentalism.

Islamic fundamentalism at the Hasanuddin University is led by LDK-MPM. Traits and characteristics Islamic fundamentalism brought by LDK-MPM are among others, rejection of modernization as it is always associated with the Western culture, rejection of diversity, and rejection of dialogue and new interpretations of the text. Basically, the Islamic movement with a fundamentalist thought pattern did not emerge spontaneously. This movement basically had existed since long ago, but political conditions at the time of the New Order, did not give enough room for them to spread the ideas because Pancasila was considered the final ideology of the state. Therefore, the LDK-MPM activists tried to avoid the ideological nature of propagation and selected activities related to discussions and religious instruction, so they could be accepted on campus due to their activities solely considered to improve students' religiosity. However, the post-reform freedom contributed to the growth of Islamic fundamentalism since the reform era allows for considerable space for individuals and groups to freely associate, assemble, and express argument.

The students' lack of comprehensive Islamic references has given the ideology of Islamic fundamentalism to thrive at UNHAS as students do not have enough resources to critique and review the notion brought by Islamic fundamentalist actors. The emergence of modernity that is always associated with the Western culture is considered by many to be bringing negative influence, so that the ideology of Islamic fundamentalism emerged as an alternative to counteract the negative excesses. The pattern of thought brought LDK-MPM which is gradual fundamentalist in nature is a means of accommodating the students' concern and at the same time avoiding extreme ways of violence. However this sort of thought has created a nature symbolic violence.

Symbolic violence is essentially dominant because it works under the most fundamental tools in human, i.e. through symbols of communication and knowledge, such as language, lifestyle, way of thinking, speech, and action, traits, and stigma, which in the end will create compliance (Bourdieu in 
Haryatmoko, 2010: 13). Symbolic violence is a catalyst that is capable of creating the psychological and physical violence that results in actual nature (Haryatmoko, 2010: 130). Physical violence is actually becoming the main purpose of symbolic violence. The thing is that we cannot sensitively realize the long term effects generated by symbolic violence, because it is traditionally wrapped neatly in the subconscious structure of the human.

\section{BIBLIOGRAPHY}

Anwar. M. Syafii. 2006. "Gerakan Muslim Modernis: Pergumulan Wacana dan Politik Pasca Orde Baru”, dalam Komaruddin Hidayat dan Ahmad Gaus (eds.), Menjadi Indonesia: 13 Abad Eksistensi Islam di Bumi Nusantara. Jakarta Selatan: Penerbit Mizan-Yayasan Festival Istiqlal.

Armstrong, Karen. 2011. Masa Depan Tuhan: Sanggahan terhadap Fundamentalisme dan Ateisme. Bandung: Penerbit Mizan.

Barr, James. 1996. Fundamentalisme. Jakarta: PT. BPK Gunung Mulia.

Burhanuddin. 2007. "The Conspiracy of Jews: The Quest for Anti-Semitism in Media Dakwah", dalam Graduate Journal of Asia-Pacific Studies 5:2 (2007), 53-76.

Damanik, Ali Said. 2002. Fenomena Partai Keadilan: Transformasi 20 Tahun Gerakan Tarbiyah di Indonesia. Jakarta Selatan: Penerbit Teraju.

Fealy, Greg dan Anthony Bubalo. 2005. Jejak Kafilah: Pengaruh Radikalisme Timur Tengah di Indonesia. Bandung: Mizan.

Haryatmoko. 2010. Dominasi Penuh Muslihat: Akar Kekerasan dan Diskriminasi. Jakarta: Penerbit Gramedia Pustaka Utama.

Hilmy, Masdar. 2010. Islamism and Democracy in Indonesia: Piety and Pragmatism. Institute of Southeast Asian Studies (ISEAS).

Hwang, Julia Chernov. 2011. Umat Bergerak: Mobilisasi Damai Kaum Islamis di Indonesia, Malaysia, dan Turki. Jakarta: Freedom Institute.

Jainuri, Ahmad. 2003. "Fundamentalisme Islam: Asal Usul dan Karakteristik", dalam Jurnal Akademia Vol. 13, hlm 1-14.

Muhtadi, Burhanuddin. 2012. Dilema PKS: Suara dan Syariah. Jakarta: Kepustakaan Populer Gramedia.

Qodir, Zuly. 2007. Islam Liberal: Paradigma Baru Wacana dan Aksi Islam Indonesia. Yogyakarta: Pustaka Pelajar.

Qodir, Zuly. 2009. Gerakan Sosial Islam: Manifesto Kaum Beriman. Yogyakarta: Pustaka Pelajar.

Rahmat, M. Imdadun. 2005. Arus Baru Islam Radikal: Transmisi Revivalisme Islam Timur Tengah Ke Indonesia. Jakarta: Penerbit Erlangga.

Taufani. 2012. Ideologi Islamisasi vs Kekerasan: Studi Respon Gerakan Dakwah Kampus terhadap Ideologi Kekerasan di Senat Fakultas Teknik Universitas Hasanuddin. Tesis: Center for Religious and Cross-Cultural Studies 
Graduate School Gadjah Mada University Yogyakarta, Indonesia.

Van Bruinessen, Martin. 2008. "Traditionalist and Islamist Pesantrens in Contemporary Indonesia”, dalam Farish A. Noor, dkk (ed.), The Madrasa in Asia: Political Activism and Transnational Linkages. Amsterdam University Press.

Van Bruinessen, Martin. 2009. "Modernism and Anti-modernism in Indonesian Muslim Responses to Globalization", paper dipresentasikan dalam workshop Islam and Development in Southeast Asia: Southeast Asian Muslim Responses to Globalization, diselenggarakan oleh JICA (Japan International Cooperation Agency) Research Institute, Singapore, 21-22 November 2009.

Wiranto, Erham Budi. 2010. Islamic Fundamentalism among Students at Natural Sciences and Social Sciences Faculties of Gadjah Mada University. Tesis: Center for Religious and Cross-Cultural Studies Graduate School Gadjah Mada University Yogyakarta, Indonesia. 